\title{
Pertumbuhan Biji Buah Naga (Hylocereus Polyrhizus) dengan Pemberian NAA dan Ekstrak Biji Jagung (Zea Mays) secara In Vitro
}

\author{
In vitro growth of Dragon Fruit Seeds (Hylocereus polyrhizus) by adding NAA and \\ Corn Seed Extract (Zea mays)
}

\author{
Rizka Widasari*, Mukarlina Zulfa Zakiah \\ Universitas Tanjungpura; Jl. Prof. Dr. H. Hadari Nawawi, Pontianak \\ Program Studi Biologi, Jurusan Biologi FMIPA Untan Kalimantan Barat 78124 \\ *Email: rizkawidasari6@gmail.com
}

(Article History: Received 25 November 2020; Revised 5 January 2021; Accepted 10 February 2021)

\begin{abstract}
ABSTRAK
Buah naga (Hylocereus polyrhizus) merupakan salah satu tanaman yang dibudidayakan di Indonesia. Perbanyakan bibit secara in vitro dengan teknologi kultur jaringan merupakan cara alternatif yang tepat untuk menyediakan bibit dalam waktu singkat dengan jumlah banyak. Penelitian ini bertujuan untuk menguji pengaruh dan konsentrasi terbaik penambahan ekstrak biji jagung dan NAA pada media tumbuh terhadap perkecambahan biji buah naga merah secara in vitro. Penelitian dilaksanakan di Laboratorium Kultur Jaringan, Jurusan Biologi, Fakultas Matematika dan Ilmu Pengetahuan Alam Universitas Tanjungpura Pontianak. Penelitian menggunakan Rancangan Acak Lengkap dengan 2 faktor perlakuan. Faktor pertama yaitu NAA dengan konsentrasi $0 \mathrm{M}, 10^{-8} \mathrm{M}, 10^{-7} \mathrm{M}$, dan $5 \times 10^{-7} \mathrm{M}$. Faktor kedua yaitu ekstrak biji jagung dengan konsentrasi $0 \%, 5 \%, 7,5 \%$, dan $10 \%$. Hasil penelitian menunjukkan pemberian ekstrak biji jagung tunggal, NAA tunggal dan kombinasi ekstrak biji jagung dan NAA memberikan pengaruh nyata terhadap tinggi planlet, namun tidak berpengaruh nyata terhadap persentase perkecambahan. Pemberian ekstrak biji jagung tunggal memberikan pengaruh nyata terhadap waktu berkecambah, sedangkan pemberian ekstrak biji jagung tunggal dan NAA tunggal berpengaruh nyata terhadap jumlah akar. Perlakuan $5.10^{-7} \mathrm{M}$ NAA $+7,5 \%$ ekstrak biji jagung menghasilkan pertumbuhan tinggi plantlet terbaik. Konsentrasi 7,5\% ekstrak biji jagung merupakan konsentrasi terbaik waktu berkecambahan biji buah naga dan konsentrasi NAA tunggal $10^{-8} \mathrm{M}$ memberikan jumlah akar terbanyak.
\end{abstract}

Kata Kunci: Pertumbuhan in vitro, Biji Buah Naga, Ekstrak Biji Jagung, NAA.

\begin{abstract}
ABSTRAK
Dragon fruit (Hylocereus polyrhizus) is one of the cultivated plants in Indonesia. In vitro propagation of seeds with the addition of synthetic growth regulators or from growth regulators from organic matter in the media, is an appropriate alternative way to provide large quantities of seeds in a short time. This study aims to determine the effect and the best effect of corn seed extract and NAA on growing media on in vitro red dragon fruit seed germination. The research was conducted at the Tissue Culture Laboratory, Department of Biology, Faculty of Mathematics and Natural Sciences, University of Tanjungpura Pontianak. The study used a completely randomized design with 2 treatment factors. The first factor is NAA with a concentration of $0 \mathrm{M}, 10^{-8} \mathrm{M}, 10^{-7} \mathrm{M}$, and $5 \times 10^{-7} \mathrm{M}$. The second factor is corn seed extract with a concentration of $0 \%, 5 \%, 7.5 \%$, and $10 \%$. The results showed that the administration of single corn seed extract, single NAA and a combination of corn seed extract and NAA had a significant effect on plantlet height, but did not significantly affect the germination percentage. The administration of single corn seed extract had a significant effect on germination time, while the administration of single corn seed extract and single NAA had a significant effect on the number of roots. The $5.10^{-7} \mathrm{M} \mathrm{NAA}+7.5 \%$ corn seed extract treatment resulted in the best plantlet height growth. The concentration of $7.5 \%$ corn seed extract was the best concentration for dragon fruit seed germination time and a single $N A A$ concentration of $10^{-8} \mathrm{M}$ gave the highest number of roots.
\end{abstract}

Keywords: In Vitro Growth, Dragon Fruit Seeds, Corn Seed Extract, NAA. 


\section{PENDAHULUAN}

Buah naga merupakan salah satu tanaman yang banyak dibudidayakan di Indonesia. Buah naga memiliki beberapa manfaat seperti dapat mencegah pendarahan dan kanker usus, penyeimbang kadar gula darah, penurun kolestrol, dan menjaga kesehatan mulut (Kristanto 2014).

Produksi buah naga dalam negeri masih sangat terbatas sehingga harganya menjadi lebih tinggi. Perbanyakan buah naga dapat dilakukan secara vegetatif dan generatif. Perbanyakan secara vegetatif dapat menggunakan stek batang atau cabang, tetapi perbanyakan dengan stek batang atau cabang mempunyai beberapa kendala seperti zat tumbuh tidak tersebar merata yang menyebabkan pertumbuhan stek tidak seragam, dan menghasilkan bibit dalam jumlah yang terbatas (Hartman dan Kester 1983). Perbanyakan secara generatif dapat menggunakan biji yang menghasilkan bibit dalam jumlah besar tetapi mudah terserang hama dan penyakit serta sensitif terhadap kekeringan atau kelebihan air pada masa perkecambahan (Cahyono 2009).

Perbanyakan secara in vitro merupakan cara yang dapat digunakan untuk menyediakan bibit dalam jumlah yang banyak dan waktu yang singkat. Perbanyakan secara in vitro ditunjang oleh komposisi media pertumbuhan yang mengandung unsur hara makro, mikro, dan vitamin. Proses pertumbuhan tanaman dapat ditingkatkan dengan penambahan zat pengatur tumbuh seperti auksin dan siktokinin dalam media. Zat pengatur tumbuh dapat diperoleh dari senyawa organik maupun sintetik (Samudin 2009).

Salah satu sumber zat pengatur tumbuh organik adalah ekstrak biji jagung. Ekstrak biji jagung muda dapat mendorong pembelahan sel, morfogenesis, dan memacu pertumbuhan tunas karena mengandung sitokinin dalam bentuk zeatin sebesar 53,94 ppm, auksin 1,67 ppm, dan giberelin 41,23 ppm (Pierik 1987; Karjadi 2002). Zat pengatur tumbuh auksin dalam jumlah tinggi pada tanaman akan merangsang inisiasi akar, dan auksin dalam jumlah seimbang dengan sitokinin akan merangsang terbentuknya kalus. Salah satu zpt (zat pengatur tumbuh) sintetik yang dapat digunakan untuk mencukupi kebutuhan auksin tanaman adalah Naphthalene Acetic Acid (NAA) (Advinda 2018). Sitokinin berperan dalam memacu pembentukan tunas dengan daya aktivitas yang kuat dalam mendorong proses pembelahan sel (George dan Sherrington 1984).

Penelitian Finna et al. (2015) memperlihatkan bahwa kombinasi air kelapa dan NAA tidak berpengaruh nyata terhadap waktu muncul kecambah dan persentase perkecambahan. Penelitian Rendani et al. (2015) menjelaskan bahwa penambahan NAA dan air kelapa tidak berpengaruh terhadap waktu muncul tunas, jumlah tunas, dan panjang tunas. Hasil penelitian Paqalla et al. (2015) menjelaskan bahwa perlakuan beberapa konsentrasi ekstrak jagung pada kultur propagul pisang ambon hijau memberikan pengaruh nyata terhadap propagul pisang ambon hijau.

Tujuan dari penelitian ini adalah untuk menguji pengaruh penambahan ekstrak biji jagung dan NAA terhadap pertumbuhan biji buah naga secara in vitro dan mengetahui konsentrasi ekstrak biji jagung dan NAA yang menghasilkan pertumbuhan terbaik pada biji buah naga secara in vitro.

\section{METODE}

\section{Alat dan Bahan}

Alat yang digunakan adalah autoklaf, blender, botol kultur beserta tutup, bunsen, cawan petri, gelas beaker, gelas ukur, hot plate, Laminar Air Flow Cabinet, magnetic stirer, $\mathrm{pH}$ indikator, pinset, pisau skalpel, pipet ukur, saringan, spatula, dan timbangan analitik.

Bahan yang digunakan adalah agar, akuades, alkohol $70 \%$, buah naga, ekstrak biji jagung, gula pasir, larutan stok, media Murasshige dan Skoog (MS), dan NAA.

\section{Rancangan Percobaan}

Rancangan percobaan yang digunakan adalah Rancangan Acak Lengkap dengan 2 
faktor. Faktor pertama yaitu NAA dengan konsentrasi yaitu $0 \mathrm{M}, 10^{-8} \mathrm{M}, 10^{-7} \mathrm{M}$, dan $5.10^{-7} \mathrm{M}$. Faktor kedua yaitu ekstrak biji jagung dengan konsentrasi yaitu 0\%, 5\%, $7,5 \%$, dan $10 \%$.

\section{Pembuatan dan sterilisasi media}

Pembuatan media dilakukan dengan cara menimbang gula pasir sebanyak $30 \mathrm{~g}$ dimasukan ke dalam gelas beaker $500 \mathrm{ml}$ kemudian ditambahkan akuades $200 \mathrm{ml}$, diaduk dengan magnetic stirer sampai gula larut. Selanjutnya dipipet larutan stok A, B, $\mathrm{C}, \mathrm{D}, \mathrm{E}, \mathrm{G}$ dan $\mathrm{H}$ masing-masing sebanyak $10 \mathrm{ml} / \mathrm{l}$, dan larutan stok F sebanyak $1 \mathrm{ml} / \mathrm{l}$ dalam gelas beaker. Agar-agar dimasukkan ke dalam gelas beaker dan ditambahkan akuades $500 \mathrm{ml}$, lalu dipanaskan hingga mendidih. Setelah mendidih, larutan stok hara, larutan gula, dan larutan agar-agar dimasukkan ke dalam gelas beaker $1000 \mathrm{ml}$, kemudian ditepatkan dengan akuades hingga volume $800 \mathrm{ml}$.

Langkah selanjutnya media dibagi menjadi 4 bagian dengan volume masingmasing sebanyak $200 \mathrm{ml}$. Kemudian media ditambah ekstrak jagung dan NAA sesuai perlakuan, selanjutnya volume masingmasing media perlakuan ditepatkan menjadi $250 \mathrm{ml}$ dengan penambahan akuades. Setelah itu diukur $\mathrm{pH}$ larutan hingga $\mathrm{pH}$ 5-6. Media disterilisasi menggunakan autoklaf pada suhu $121^{\circ} \mathrm{C}$ dan tekanan 2 atm selama 20 menit.

\section{Parameter Pengamatan}

Parameter yang diamati yaitu waktu berkecambah biji (hari), persentase perkecambahan $(\%)$, rerata, rerata tinggi planlet $(\mathrm{cm})$, rerata jumlah daun (helai), rerata jumlah akar (buah).

\section{HASIL DAN PEMBAHASAN Waktu Berkecambah Biji}

Hasil analisis statistik menunjukkan bahwa faktor tunggal ekstrak biji jagung $\left(\mathrm{F}_{15,32}=3,020, \quad p=0,044 ; \quad\right.$ ANAVA) berpengaruh nyata terhadap waktu berkecambah, sedangkan faktor tunggal NAA $\left(\mathrm{F}_{15,32}=1,970, p=0,138\right.$; ANAVA $)$ serta faktor interaksi NAA dan ekstrak biji jagung $\left(\mathrm{F}_{15,32}=1,404, \quad p=0,228 ; \quad\right.$ ANAVA $)$ tidak berpengaruh nyata terhadap waktu berkecambah (Tabel 1 dan Gambar 1).

Tabel 1. Rerata waktu berkecambah biji buah naga merah dengan perlakuan NAA dan ekstrak biji jagung pada kultur berumur 4 minggu

\begin{tabular}{cccccc}
\hline NAA & \multicolumn{4}{c}{ Ekstrak biji jagung (\%) } & Rat \\
\cline { 2 - 5 }$(\mathrm{M})$ & 0 & 5 & 7,5 & 10 & $\begin{array}{c}\text { a- } \\
\text { rata }\end{array}$ \\
\hline 0 & $9,0^{\text {ns }}$ & $8,6^{\text {ns }}$ & $7,3^{\text {ns }}$ & $9,0^{\text {ns }}$ & $8,5 \mathrm{~A}$ \\
$10^{-8}$ & $8,3^{\text {ns }}$ & $9,0^{\text {ns }}$ & $9,6^{\text {ns }}$ & $8,6^{\text {ns }}$ & $8,9 \mathrm{~A}$ \\
$10^{-7}$ & $7,3^{\text {ns }}$ & $8,6^{\text {ns }}$ & $8,3^{\text {ns }}$ & $9,3^{\text {ns }}$ & $8,4 \mathrm{~A}$ \\
$5.10^{-7}$ & $7,6^{\text {ns }}$ & $8,6^{\text {ns }}$ & $9,0^{\text {ns }}$ & $9,3^{\text {ns }}$ & $8,6 \mathrm{~A}$ \\
\hline $\begin{array}{c}\text { Rata- } \\
\text { rata }\end{array}$ & $8,0 \mathrm{~A}$ & $8,7 \mathrm{AB}$ & $8,6 \mathrm{AB}$ & $9,0 \mathrm{~B}$ & \\
\hline
\end{tabular}

Keterangan: Angka yang diikuti oleh huruf besar yang sama pada baris dan kolom menunjukkan hasil yang tidak berbeda nyata pada taraf 5\% berdasarkan uji lanjut Duncan.

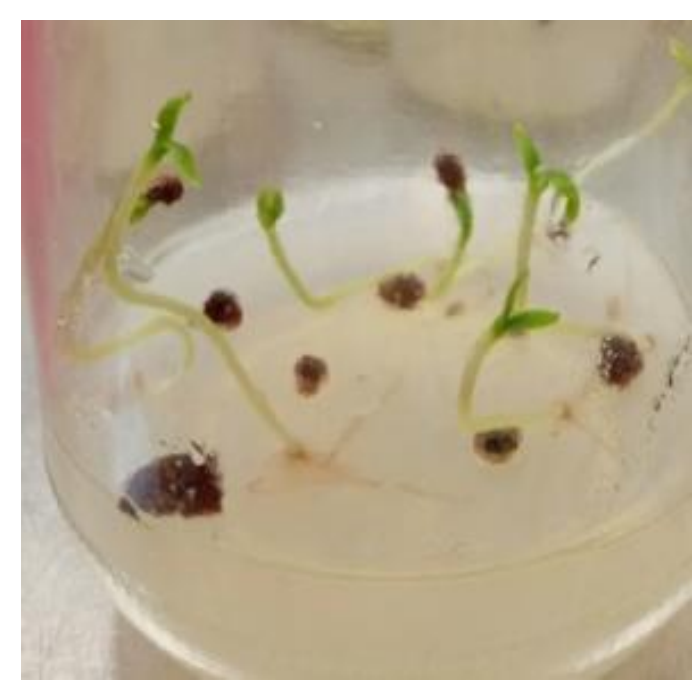

Gambar 1. Konsentrasi 0\% ekstrak biji jagung pada parameter waktu berkecambahan biji.

Hasil penelitian menunjukkan bahwa waktu berkecambah biji buah naga hanya dipengaruhi oleh perlakuan penambahan ekstrak biji jagung. Perlakuan ekstrak biji jagung 5\% dan 7,5\% memberikan hasil yang tidak beda nyata dengan waktu perkecambahan tanpa ekstrak biji jagung. Pemberian ekstrak biji jagung 5\% dan 7,5\% menghasilkan waktu berkecambah biji buah naga lebih cepat dibandingkan perlakuan $10 \%$. Kondisi ini menunjukkan bahwa 
kandungan zpt endogen, dan zpt eksogen berupa auksin, sitokinin dan giberelin di dalam ekstrak biji jagung 5\% dan 7,5\% sudah mencukupi untuk mempercepat waktu perkecambahan biji buah naga merah. Menurut Gardner et al. (1991), giberelin dapat memperpendek masa dormansi biji, sehingga biji akan lebih cepat untuk memulai proses perkecambahan.

Hopkins (2008); Gardner et al. (1991) menjelaskan bahwa giberelin berperan dalam fase berkecambah dan akhir fase dormansi melalui pembentukan enzim amilase. Enzim amilase berperan memecah senyawa amilum pada endosperm (cadangan makanan) menjadi glukosa. Glukosa digunakan sebagai sumber energi untuk proses perkecambahan dan pertumbuhan. Auksin dan sitokinin bekerja sama dalam pembelahan sel, pemanjangan dan pembesaran sel pada meristem pucuk dan meristem akar embrio.

\section{Persentase Perkecambahan}

Hasil analisis statistik menunjukkan bahwa faktor tunggal NAA $\left(\mathrm{F}_{15,32}=0,020\right.$, $p=0,996$; ANAVA), faktor tunggal ekstrak biji jagung $\left(\mathrm{F}_{15,32}=0,673, p=0,575\right.$; ANAVA) serta faktor interaksi NAA dan ekstrak biji jagung $\left(\mathrm{F}_{15,32}=0,673, \quad p=0,727\right.$; ANAVA $)$ tidak berpengaruh nyata terhadap persentase perkecambahan (Tabel 2).

Tabel 2. Rerata persentase perkecambahan (\%) biji buah naga merah dengan perlakuan NAA dan ekstrak biji jagung umur 4 minggu

\begin{tabular}{ccccc}
\hline NAA & \multicolumn{4}{c}{ Ekstrak biji jagung (\%) } \\
\cline { 2 - 5 }$(\mathrm{M})$ & 0 & 5 & 7,5 & 10 \\
\hline 0 & $50,0^{\text {ns }}$ & $63,3^{\text {ns }}$ & $60,0^{\text {ns }}$ & $63,3^{\text {ns }}$ \\
$10^{-8}$ & $60,0^{\text {ns }}$ & $60,0^{\text {ns }}$ & $63,3^{\text {ns }}$ & $56,6^{\text {ns }}$ \\
$10^{-7}$ & $53,3^{\text {ns }}$ & $60,0^{\text {ns }}$ & $66,6^{\text {ns }}$ & $60,0^{\text {ns }}$ \\
$5.10^{-7}$ & $63,3^{\text {ns }}$ & $63,3^{\text {ns }}$ & $56,6^{\text {ns }}$ & $56,6^{\text {ns }}$ \\
\end{tabular}

Semua perlakuan yang diberikan tidak memengaruhi persentase perkecambahan biji buah naga, dengan persentase perkecambahan berkisar antara $50 \%$ sampai
66,6\%. Hasil ini menunjukkan bahwa interaksi antara zpt endogen dengan zpt yang terkandung dalam semua konsentrasi perlakuan ekstrak biji jagung dan NAA yang diberikan belum mampu untuk meningkatkan daya kecambah pada biji buah naga. Menurut Lestari et al. (2013) rasio hormon pada setiap biji berbeda-beda sehingga penambahan zpt eksogen dengan konsentrasi yang tepat agar dapat memacu pertumbuhan dan perkembangan biji.

Menurut George dan Sherrington (1984) bahwa rasio sitokinin dan auksin yang tidak sesuai pada dapat mengakibatkan pertumbuhan eksplan biji menjadi terhambat. Hasil penelitian ini sejalan dengan penelitian Finna et al. (2015) bahwa penambahan air kelapa dengan konsentrasi $5 \%, 10 \%, 15 \%$ dan NAA dengan konsentrasi $5.10^{-6} \mathrm{M}, 10^{-6} \mathrm{M}, 10^{-7} \mathrm{M}$ tidak berpengaruh nyata terhadap persentase perkecambahan pada kultur biji buah naga (H. polyrhizus).

\section{Rerata Tinggi Planlet}

Hasil analisis statistik menunjukkan bahwa faktor tunggal NAA $\left(\mathrm{F}_{15,32}=20,908\right.$, $p=0,000$; ANAVA) dan ekstrak biji jagung $\left(\mathrm{F}_{15,32}=16,636, \quad p=0,000 ;\right.$ ANAVA $)$ serta interaksi NAA dan ekstrak biji jagung berpengaruh nyata terhadap tinggi planlet $\left(\mathrm{F}_{15,32}=2,831, p=0,014\right.$; ANAVA) (Tabel 3).

Hasil analisis lanjut Duncan menunjukkan bahwa perlakuan $5.10^{-7} \mathrm{M}$ $\mathrm{NAA}+7,5 \%$ ekstrak biji jagung menunjukkan hasil berbeda nyata dengan perlakuan kontrol dan semua perlakuan lainnya, serta menghasilkan rerata planlet tertinggi yaitu $3,8 \mathrm{~cm}$.

Perlakuan interaksi $5.10^{-7} \mathrm{M}$ NAA $+7,5 \%$ ekstrak biji jagung menunjukkan tinggi planlet tanaman buah naga merah tertinggi yaitu $3,8 \mathrm{~cm}$. Hasil ini diduga bahwa interaksi antara $5.10^{-7} \mathrm{M}$ NAA dan zpt auksin, sitokinin, dan giberelin dalam ekstrak biji jagung 7,5\% yang ditambahkan pada media serta zpt endogen pada biji buah naga diduga mampu menghasilkan perimbangan yang tepat untuk memacu pembelahan sel pada meristem apeks pucuk 
yang menghasilkan pertumbuhan tinggi planlet buah naga merah yang optimal.

Tabel 3. Rerata tinggi planlet $(\mathrm{cm})$ buah naga merah dengan perlakuan NAA dan ekstrak biji jagung umur 12 minggu

\begin{tabular}{|c|c|c|c|c|c|}
\hline \multirow{2}{*}{$\begin{array}{l}\text { NAA } \\
\text { (M) }\end{array}$} & \multicolumn{4}{|c|}{ Ekstrak biji jagung (\%) } & \multirow{2}{*}{$\begin{array}{l}\text { Rata- } \\
\text { rata }\end{array}$} \\
\hline & (0) & (5) & $(7,5)$ & (10) & \\
\hline 0 & 3,0 & $\begin{array}{l}3,1 \\
\text { abc }\end{array}$ & $\begin{array}{l}3,4 \\
\text { defg }\end{array}$ & $\underset{\mathrm{a}}{3,0}$ & $3,1 \mathrm{~A}$ \\
\hline $10^{-8}$ & $\begin{array}{c}3,1 \\
\mathrm{ab}\end{array}$ & $\begin{array}{l}3,3 \\
\text { bcd }\end{array}$ & $\begin{array}{l}3,6 \\
\text { fgh }\end{array}$ & $\begin{array}{l}3,5 \\
\text { fgh }\end{array}$ & $3,3 \mathrm{~B}$ \\
\hline $10^{-7}$ & $3,4_{\mathrm{f}}^{\mathrm{de}}$ & $\begin{array}{l}3,5 \\
\text { efg }\end{array}$ & $\begin{array}{l}3,4 \\
\text { defg }\end{array}$ & $\begin{array}{c}3,6 \\
\mathrm{gh}\end{array}$ & $3,5 \mathrm{C}$ \\
\hline $5.10^{-7}$ & $3,3^{c d}$ & $\begin{array}{l}3,4 \\
\text { defg }\end{array}$ & $\mathbf{3 , 8}$ & $\begin{array}{c}3,7 \\
\mathrm{~h}\end{array}$ & $3,5 \mathrm{C}$ \\
\hline $\begin{array}{c}\text { Rata- } \\
\text { rata }\end{array}$ & $\begin{array}{c}3,2 \\
\mathrm{~A}\end{array}$ & $\begin{array}{c}3,3 \\
\mathrm{~B} \\
\end{array}$ & $3,5 \mathrm{C}$ & $3,5 \mathrm{C}$ & \\
\hline
\end{tabular}

Keterangan: Faktor A, B, AxB berbeda nyata. Angka-angka pada setiap baris dan kolom yang diikuti oleh huruf besar yang sama menunjukan hasil yang tidak berbeda nyata terhadap masing-masing faktor tunggal pada uji Duncan's taraf 5\% dan angkaangka pada setiap baris dan kolom yang diikuti oleh huruf kecil yang sama menunjukkan hasil yang tidak berbeda nyata pada uji Duncan's taraf 5\%.

Hasil tinggi planlet yang besar pada penambahan $5.10^{-7} \mathrm{M}$ NAA yang di kombinasikan 7,5\% ekstrak biji jagung menunjukan bahwa ada pengaruh giberelin yang terdapat pada ekstrak biji jagung terhadap pembelahan dan pemanjangan sel kecambah buah naga. Peningkatan giberelin pada suatu tanaman selalu diiringi oleh peningkatan auksin dan sitokinin dan bersinergi membantu meningkatkan pertumbuhan dan perkembangan tanaman (Salisbury dan Ross 1995).

Giberelin akan meningkatkan aktivitas enzim proteinase yang mengubah protein menjadi asam amino salah satunya asam amino triptopan yang merupakan pra zat dalam sintesis auksin (Goldsorthy dan Fisher 1992). Menurut Wattimena (1992); Satria et al. (1999) kombinasi sitokinin dan auksin serta interaksinya yang tepat dengan $\mathrm{zpt}$ endogen mampu mendorong pembelahan sel dan menentukan arah diferensiasi sel tanaman. Penelitian Finna et al. (2016) pada pertumbuhan in vitro biji buah naga menunjukkan hasil yang sejalan dengan penelitian ini yaitu bahwa interaksi NAA dan air kelapa yang ditambahkan pada media meningkatkan tinggi plantlet biji buah naga.

\section{Rerata Jumlah Daun}

Berdasarkan hasil pengamatan terhadap rerata jumlah daun dari awal setelah tanam sampai umur kultur 12 minggu tidak terjadi penambahan jumlah daun, hasil pengamatan dapat dilihat pada Tabel 4.

Tabel 4. Rerata jumlah daun (helai) planlet buah naga merah dengan perlakuan NAA dan ekstrak biji jagung pada kultur berumur 12 minggu

\begin{tabular}{ccccc}
\hline \multirow{2}{*}{$\begin{array}{c}\text { NAA } \\
\text { (M) }\end{array}$} & \multicolumn{4}{c}{ Ekstrak biji jagung (\%) } \\
\cline { 2 - 5 } & 0 & 5 & 7,5 & 10 \\
\hline 0 & 2,0 & 2,0 & 2,0 & 2,0 \\
$10^{-8}$ & 2,0 & 2,0 & 2,0 & 2,0 \\
$10^{-7}$ & 2,0 & 2,0 & 2,0 & 2,0 \\
$5.10^{-7}$ & 2,0 & 2,0 & 2,0 & 2,0 \\
\hline
\end{tabular}

Perlakuan tunggal NAA dan tunggal ekstrak biji jagung serta interaksi antara NAA dan ekstrak biji jagung tidak berpengaruh nyata terhadap jumlah daun plantlet buah naga merah. Perlakuan NAA maupun ekstrak biji jagung yang tidak memengaruhi pertumbuhan daun plantlet tanaman buah naga diduga bahwa aktivitas zpt sintetik NAA dan zpt yang terkandung dalam ekstrak biji jagung pada konsentrasi yang ditambahkan pada media uji belum mencapai perimbangan yang tepat untuk memacu pembelahan sel pada primordia daun, tetapi lebih mengarah pada induksi pertumbuhan primordia pucuk dan primordia akar plantlet. Dugaan ini diperkuat dengan hasil tinggi plantlet dan jumlah akar yang terbentuk.

Basri (2011) menyatakan bahwa efektifitas penambahan sitokinin maupun auksin eksogen bergantung pada konsentrasi zpt endogen yang ada pada jaringan tanaman. Menurut Hartati et al. (2016) arah 
pertumbuhan pada tanaman secara in vitro dikendalikan oleh interaksi dan perimbangan yang tepat antara zat pengatur tumbuh, endogen dengan zpt eksogen. Penelitian Oktaviana et al. (2015) juga menunjukkan hasil yang sama dengan penelitian ini yaitu penambahan sitokinin sintetik BAP (Benzyl Amino Purin) dan ekstrak tomat tidak berpengaruh nyata terhadap jumlah daun eksplan mahkota nanas (Ananas comosus).

\section{Rerata Jumlah Akar}

Hasil analisis statistik menunjukkan bahwa faktor tunggal NAA $\left(\mathrm{F}_{15,32}=70,327\right.$, $p=0,000$; ANAVA) dan ekstrak biji jagung $\left(\mathrm{F}_{15,32}=4,197, \quad p=0,013 ; \quad\right.$ ANAVA) berpengaruh nyata terhadap jumlah akar, sedangkan faktor interaksi NAA dan ekstrak biji jagung tidak berpengaruh nyata terhadap jumlah akar $\quad\left(\mathrm{F}_{15,32}=1,882, \quad p=0,091\right.$; ANAVA) (Tabel 5 dan Gambar 2).

Tabel 5. Rerata jumlah akar planlet buah naga merah dengan perlakuan NAA dan ekstrak biji jagung umur 12 minggu

\begin{tabular}{cccccc}
\hline NAA & \multicolumn{3}{c}{ Ekstrak biji jagung $(\%)$} & Rata- \\
\cline { 2 - 5 }$(\mathrm{M})$ & 0 & 5 & 7,5 & 10 & rata \\
\hline 0 & $1,6^{\text {ns }}$ & $1,6^{\text {ns }}$ & $1,8^{\text {ns }}$ & $1,9^{\text {ns }}$ & $1,7 \mathrm{~A}$ \\
$10^{-8}$ & $2,5^{\text {ns }}$ & $2,4^{\text {ns }}$ & $2,8^{\text {ns }}$ & $2,7^{\text {ns }}$ & $\mathbf{2 , 6 ~ C}$ \\
$10^{-7}$ & $2,3^{\text {ns }}$ & $3,1^{\text {ns }}$ & $2,3^{\text {ns }}$ & $2,4^{\text {ns }}$ & $2,5 \mathrm{~B}$ \\
$5.10^{-7}$ & $2,2^{\text {ns }}$ & $2,3^{\text {ns }}$ & $2,5^{\text {ns }}$ & $2,3^{\text {ns }}$ & $2,3 \mathrm{~B}$ \\
\hline $\begin{array}{c}\text { Rata- } \\
\text { rata }\end{array}$ & $2,2 \mathrm{~A}$ & $\mathbf{2 , 4 B}$ & $2,3 \mathrm{~B}$ & $2, \mathrm{~B}$ & \\
\hline
\end{tabular}

Keterangan: Angka yang diikuti oleh huruf yang sama menunjukkan hasil yang tidak berbeda nyata pada taraf 5\% lanjut Duncan.

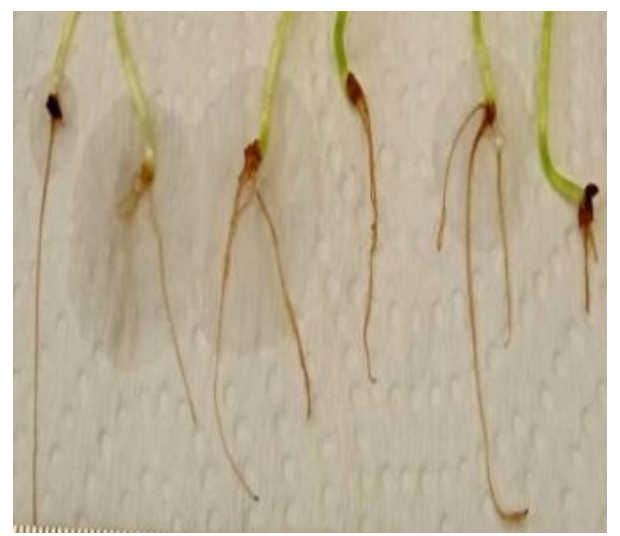

Gambar 2. Jumlah akar biji buah naga merah pada konsentrasi $0 \mathrm{M} \mathrm{NAA}+5 \%$ ekstak biji jagung.
Perlakuan tunggal NAA konsentrasi $10^{-8}$ $\mathrm{M}$ memberikan hasil terbaik untuk jumlah akar yaitu 2,6 buah. Jumlah akar yang terbentuk ini lebih banyak dibandingkan jumlah akar pada konsentrasi perlakuan ekstrak biji jagung tunggal 5\% dengan rerata jumlah akar 2,4 dan perlakuan konsentrasi NAA yang lebih tinggi yaitu $10^{-7} \mathrm{M}$ dan $5 \cdot 10^{-7} \mathrm{M}$ (2,5 akar dan 2,3 akar). Hal ini diduga bahwa penambahan $10^{-8} \mathrm{M}$ NAA mampu meningkatkan rasio auksin terhadap sitokinin di dalam jaringan tanaman sehingga dapat mencapai perimbangan yang tepat untuk memacu pembentukan primordia akar plantlet buah naga merah. Wattimena (1992) menyatakan bahwa pada level auksin yang lebih tinggi dari pada sitokinin, maka morfogenesis jaringan akan lebih mengarah pada pembentukan akar, tetapi auksin yang terlalu tinggi akan memacu disintesisnya etilen yang akan menghambat pertumbuhan akar.

\section{KESIMPULAN}

Pemberian ekstrak biji jagung tunggal, NAA tunggal dan kombinasi ekstrak biji jagung dan NAA memberikan pengaruh nyata terhadap tinggi planlet, namun tidak berpengaruh nyata terhadap persentase perkecambahan dan jumlah daun. Pemberian ekstrak biji jagung tunggal memberikan pengaruh nyata terhadap waktu berkecambah, sedangkan pemberian ekstrak biji jagung tunggal dan NAA tunggal berpengaruh terhadap jumlah akar. Konsentrasi $5 \cdot 10^{-7} \mathrm{M}$ NAA $+7,5 \%$ ekstrak biji jagung merupakan konsentrasi terbaik untuk pertumbuhan tinggi plantlet yaitu 3,8 $\mathrm{cm}$. Konsentrasi 7,5\% ekstrak biji jagung merupakan konsentrasi terbaik untuk waktu berkecambahan biji buah naga. Konsentrasi NAA tunggal $10^{-8} \mathrm{M}$ memberikan hasil jumlah akar terbanyak yaitu 2,6 buah akar.

\section{DAFTAR PUSTAKA}

Advinda L (2018) Dasar-dasar Fisiologi Tumbuhan, Budi Utama, Yogyakarta. Basri A (2011) Prinsip Dasar Teknik Kultur Jaringan, Allfabeta, Bandung. 
Cahyono B (2009) Buah Naga, Pustaka Mina, Jakarta.

Mukarlina F \& Linda R (2015) Pertumbuhan In Vitro Biji Buah Naga Merah (Hylocereus polyrhizus) dengan Penambahan Air Kelapa dan NAA. Jurnal Protobiont 4(3): 113-117.

Gardner FP, Pearce RB \& Mitchell (1991) Fisiologi Tanaman Budidaya, Penerbit UI, Jakarta.

George EF \& Sherrington PD (1984) Plant Propagation By Tissue Culture, Exegetics Limited, England.

Goldsorthy PR \& Fisher NM (1992) Fisiologi Tanaman Budidaya Tropik, Universitas Gadjah Mada Press, Yogyakarta.

Hartman \& Kester (1983) Plant Propagation Principle and Practise. Prentice Hall, Internasional Inc Engelwoods Clifs, New Jersy.

Hartati S, Budiyono A \& Cahyono O (2016) Pengaruh NAA dan BAP terhadap pertumbuhan subkultur anggrek hasil persilangan Dendrobium biggibum X Dendrobium liniale. Jurnal of Sustainable Agriculture 31(1): 33-37.

Hopkins WG (2008) Introduction to Plant Physiology, Wiley Global Education Singapore.

Kristianto D (2014) Berkebun Buah Naga, Penebar Swadaya, Jakarta.

Karjadi (2002) Metode Kultur Jaringan Tanaman, Institut Teknologi Bandung, Bandung.
Oktaviana MA, Linda R \& Mukarlina (2015) Pertumbuhan Tunas Mahkota Nanas (Ananas comosus) secara In Vitro dengan Penambahan Ekstrak Tomat (Solanum lycopersicum L.) dan BAP, Jurnal Protobiont 4(3): 109112.

Paqalla B, Latunra I \& Baharuddin (2015) Respon Pertumbuhan Propagul Pisang Ambon Hijau (Musa paradisiaca Colla) pada Beberapa Konsentrasi Ekstrak Jagung Muda Secara In Vitro, Jurusan Biologi, FMIPA Yogyakarta.

Pierik RLM (1987) In Vitro Culture Of Higher Plants, Martinus Nijhoff Publisher, London.

Rendani B, Linda R \& Mukarlina (2015) Pertumbuhan Secara In Vitro Tunas Buah Naga Merah (Hylocereus polyrhizus) dengan Penambahan NAA dan Air Kelapa, Jurnal Protobint 4(3): 103-108.

Salisbury FB \& Ross CW, (1995) Fisiologi Tumbuhan Jilid 3, Penerbit ITB, Bandung.

Samudin S (2009) Pengaruh Kombinasi Auksin-Sitokinin Terhadap Pertumbuhan Buah Naga, Media Litbang Sulteng 2(1): 62-66.

Satria B, Dwipa \& Jamsari (1999) Regenerasi Kalus Manggis (Garcinia mangostana L.) Melalui Kultur In vitro, Jurnal Stigma 7(1): 56-60.

Wattimena GA (1992) Bioteknologi Tanaman, Dekdikbud Dirjen Pendidikan Tinggi Bioteknologi IPB, Bogor. 